\title{
Indicators that determine disease course in COVID-19 patients
}

\author{
Osman Uzundere, M.D., ${ }^{1}$ 다 Cem Kıvılcım Kaçar, M.D., ${ }^{1}$ - Hakan Akelma, M.D., ${ }^{1}$

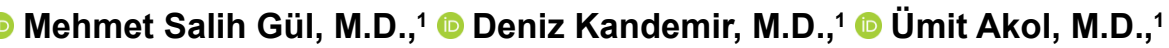 \\ (1) Abdulkadir Yektaş, M.D. ${ }^{2}$
}

\begin{abstract}
1Department of Anesthesiology and Reanimation, University of Health Sciences Diyarbakır Gazi Yaşargil Training and Research Hospital, Diyarbakır-Turkey

${ }^{2}$ Department of Intensive Care Unit, University of Health Sciences Diyarbakır Gazi Yaşargil Training and Research Hospital, Diyarbakır-Turkey
\end{abstract}

\begin{abstract}
BACKGROUND: In this study, it was tried to determine the factors affecting the clinical process in patients who were followed up in hospital for coronavirus disease-2019 (COVID-19).

METHODS: The study, which was designed as a single-center and retrospective cohort, included 658 patients admitted to the service due to COVID-19. The patients were grouped and compared as the patients followed up in the wards (Group I) and those admitted to ICU (Group 2), between those who were intubated (Group I) in the ICU and those who were not (Group NI), and between patient groups who died (Group M) and survived (Group NM) among those who were intubated.

RESULTS: Of the 658 patients hospitalized in the wards, 566 (86\%) were discharged and 99 (I4\%) were later admitted to the ICU. The mortality rate for the 658 patients that were followed up was found to be $7.75 \%$. When Groups I and 2 were compared, it was observed that the patients in Group 2 had more comorbidity and higher KDIGO stages $(p<0.001)$. In addition, patients in Group 2 had older age, higher APACHE II and SOFA scores, high WBC counts, neutrophil counts, lymphocyte counts, N/L ratio, CRP, LDH, CK, PTZ, D-dimer, procalcitonin, and ferritin values (all values $\mathrm{p}<0.00 \mathrm{I}$, for $\mathrm{CK} \mathrm{p}=0.034$ ). When the patients in Group I and Group $\mathrm{NI}$ were compared, it was observed that the patients in Group I had more comorbidities and higher mortality rate $(p<0.00 \mathrm{I})$. In addition, patients in Group I had older age, high D-dimer, and ferritin levels ( $p=0.008 ; 0.01 \mathrm{I}$, and 0.043 , respectively). When the patients in Group M and Group NM were compared, it was observed that the patients in Group M were mostly males $(p=0.017)$ and were mostly in KDIGO Stages I and 2 ( $p=0.005)$. In addition, it was found that the CRP and LDH levels of patients in Group M were significantly higher than those in Group NM ( $p=0.018$ and 0.023 , respectively).
\end{abstract}

CONCLUSION: Comorbidity, clinical features, and laboratory findings are parameters that can help in predicting the clinical course of hospitalized patients due to COVID-19.

Keywords: Clinical features; COVID-19; intensive care unit.

\section{INTRODUCTION}

Toward the end of December 2019, the pneumonia epidemic caused by the severe acute respiratory syndrome coronavirus-2 (SARS-CoV-2) virus, a novel beta coronavirus, emerged in Wuhan, China's Hubei province, and rapidly spread around the world. ${ }^{[1]}$ As of March II, 2020, there were 80,955 cases and 3135 deaths in China, and 37,364 cases and II 30 deaths worldwide. Considering this, the World Health Organization (WHO) declared this disease a pandemic. ${ }^{[1]}$ As of December I, 2020, the WHO reported $62,662,181$ confirmed cases and I,460,223 deaths worldwide. ${ }^{[2]}$

Cite this article as: Uzundere O, Kaçar CK, Akelma H, Gül MS, Kandemir D, Akol Ü, et al. Indicators that determine disease course in COVID-19 patients. Ulus Travma Acil Cerrahi Derg 2021;27:668-676.

Address for correspondence: Osman Uzundere, M.D.

SBÜ Diyarbakır Gazi Yaşargil Eğitim ve Araştırma Hastanesi Anesteziyoloji ve Reanimasyon Anabilim Dalı, Diyarbakır, Turkey

Tel: +90 412 - 2580060 / 3148 E-mail: osmanuzundere@gmail.com 
Patients with coronavirus disease 2019 (COVID-19) have been observed to have various comorbidities, especially hypertension and diabetes. ${ }^{[3]}$ It has been reported that $20-51 \%$ of patients have at least one comorbidity. ${ }^{[4]}$ The major risk factors for an increased mortality risk in COVID- 19 patients are age and comorbidities (cardiovascular diseases, lung disease, obesity, and diabetes)..$^{[5-7]}$

While planning this study, we chose patients who were hospitalized due to COVID-19 under the same conditions and were treated with the same treatment protocol. We hypothesized that there would be a difference in terms of comorbidities, clinical findings, and laboratory results between the patients followed up in the wards and those admitted to ICU, between those who were intubated in the ICU and those who were not, and between patient groups who died and survived among those who were intubated.

Based on this, our study aimed to determine the clinical and laboratory characteristics of patients who were admitted to the ICU, intubated there, and dead after intubation.

\section{MATERIALS AND METHODS}

\section{Study Design, Population, and Data}

This study was performed in the Diyarbakir Gazi Yasargil Training and Research Hospital between March 22, 2020, and June 15, 2020, with the approval of the institutional ethics committee (approval no. 470, dated May 15, 2020). This retrospective study was conducted in accordance with the 2008 Helsinki Declaration criteria.

The study included 697 patients hospitalized in the hospital wards with suspected COVID-19. The study excluded patients with incomplete data, patients who were intubated at their first ICU admission, patients who were directly admitted to the ICU, patients aged under 18 years, patients who suffered a cardiopulmonary arrest after ICU admission and were intubated and did not return to sinus rhythm, and 39 patients who were not considered to have COVID-19. The study was completed using data from 658 patients. Nasopharyngeal swab samples were taken at least 2 times from patients hospitalized with the pre-diagnosis of COVID-19 and the presence of SARS-CoV-2 was confirmed by reverse transcriptase polymerase chain reaction (RT-PCR). Patients were admitted to COVID-19 wards and then to the ICU according to the temporary guidelines provided by the $\mathrm{WHO}^{[8]}$ and the Scientific Advisory Board of the Ministry of Health of the Republic of Turkey. ${ }^{[9]}$ The standard treatments of the patients were arranged according to these guidelines. Standard treatments applied to patients in the ward included: (I) oxygen therapy (nasal cannula/mask oxygen inhalation) according to the degree of respiratory distress and hypoxia in the patient, (2) appropriate fluid and electrolyte replacements when necessary, (3) antiviral therapy (hy- droxychloroquine and favipiravir), (4) appropriate antibiotic treatment when secondary bacterial infection is considered (with the opinion of an infectious diseases specialist), (5) respiratory exercises accompanied by a physiotherapist, and (6) other treatments (therapies such as steroid, tocilizum$\mathrm{ab}$, and intravenous immunoglobulin were administered in eligible patients according to the decision of the hospital scientific board). Indications for ICU admission were as follows: Tachypnea (30 breaths/min) or dyspnea; use of extra respiratory muscles; $\mathrm{SpO}_{2}$ level below of $\leq 90 \%$ despite oxygen support with nasal cannula or mask oxygen inhalation; bilateral diffuse pneumonia symptom detected on chest radiography or computed tomography (CT); and $\mathrm{PaO}_{2} / \mathrm{FiO}_{2}$ ratio of $<300$, and developed or had complications including severe pneumonia, ARDS, sepsis/septic shock, and acute renal failure.

In the study, patients who were followed up and discharged from the wards were included in Group I, whereas patients who were later admitted to the ICU during their follow-up in the wards were included in Group 2. These two groups were compared according to their demographic, clinical, and laboratory findings during their first hospitalization. Among the patients admitted to the ICU, those who were intubated (Group I) and those who were not intubated (Group NI) were compared in terms of their characteristics during their first admission to the ICU. Finally, patients who were intubated during their follow-up in the ICU were divided into two groups as those who died (Group M) and those who survived (Group NM), and were compared in terms of their demographic, clinical, and laboratory findings at the time of first intubation. The differences between the patients admitted to the ward or the ICU, those intubated and non-intubated, and those who died or survived after intubation were examined. The study design has been depicted in the form of a flow chart (Fig. I).

Patient data were obtained using patient file records and hospital information system. The study considered demographic data of the patients; CT results; Acute Physiology and Chronic Health Evaluation II (APACHE II), Sequential Organ Failure Assessment (SOFA), and Kidney Disease: Improving Global Outcomes (KDIGO) scores; laboratory findings (white blood cell [WBC] count, neutrophil count, lymphocyte count, neutrophil/lymphocyte [N/L] ratio, platelet count, creatine kinase [CK] levels, lactate dehydrogenase (LDH) levels, C-reactive protein (CRP) levels, prothrombin time (PTZ), activated partial thromboplastin time (aPTT), D-dimer levels, procalcitonin (PCT) levels, and ferritin levels) on the day of admission to the wards, admission to the ICU, and intubation; and length of stay in the ICU, whether they were intubated after lying down, and whether they died after intubation. Chest CT results were examined under three categories as stated in the literature: ${ }^{[10,11]}$ The presence or absence of typical COVID-19 findings (ground glass opacities, consolidation, adjacent pleura thickening, interlobular septal thickening, air bronchograms, etc.) or the presence of atypical findings. 


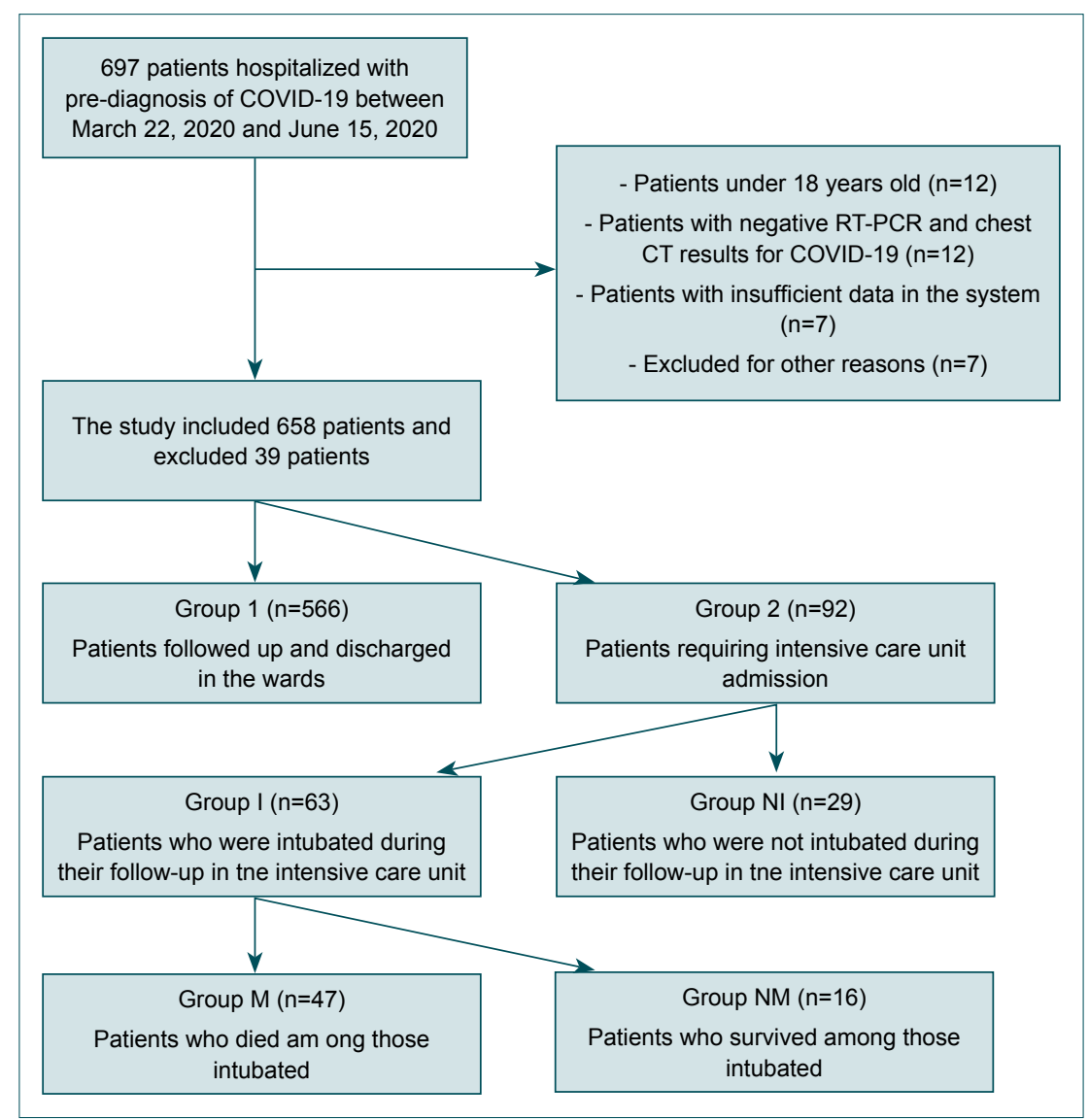

Figure 1. The study design.

\section{Statistical Analysis}

Statistical analyses were conducted using SPSS version 16.0 for Windows (SPSS Inc., Chicago, IL, USA). Continuous data were expressed as means with minimum-maximum and categorical data as frequencies with percentages. Categorical data were compared using the Chi-squared and Fisher's exact tests. The Kolmogorov-Smirnov test was used to determine whether the numerical data were normally distributed. Such data were then compared using the Student's t-test. The Mann-Whitney $U$ test was used to compare data that were not normally distributed. $\mathrm{P}<0.05$ was considered statistically significant.

\section{RESULTS}

Of the 658 patients hospitalized in the wards, 566 (86\%) were discharged and 92 (14\%) were later admitted to the ICU. RT-PCR results of 353 patients (53.6\%) were found to be positive in the first nasopharyngeal samples. During our study, none of the patients followed up in wards died; however, $5 \mathrm{I}$ patients admitted to the ICU died. The mortality rate for the 658 patients that were followed up was found to be $7.75 \%$. The most common comorbidity in the patients included in the study was cardiovascular disease, which was reported in 159 (43.2\%) patients. Among the cardiovascular diseases, the most common was hypertension ( 113 patients,
$30.7 \%$ ). Details of the clinical characteristics and comorbidities are given in Table I.

Among the patients hospitalized due to COVID-19, when the values of patients discharged from hospital (Group I) and those later admitted to the ICU (Group 2) were compared, a statistically significant difference was observed in terms of KDIGO values. The number of patients in KDIGO Stage I, Stage 2, and Stage 3 was higher than expected in patients admitted to the ICU $(P<0.00 I)$. When the two groups were compared in terms of their chest $C T$ results, the number of patients without any chest CT findings was significantly higher than expected in patients followed up in the wards (Group I=72 and Group 2=4); COVID-compliant chest $\mathrm{CT}$ result was at the expected rate in both groups; however, the number of patients with atypical/suspicious results on the chest $\mathrm{CT}$ was higher than expected in patients admitted to the ICU $(p=0.03)$. When the patients were compared in terms of comorbidities, the prevalence of comorbidities was significantly higher than expected in Group 2 patients $(p<0.00 \mathrm{I})$ (Table 2$)$.

When the patients in the groups were compared in terms of age, the mean age of the patients in Group I was significantly lower than those in Group 2 (Group I=46.33, Group $2=65.76)(p<0.00 I)$. APACHE II and SOFA scores were sig- 
Table I. Clinical characteristics and comorbidities in patients with COVID-19

\begin{tabular}{|c|c|c|}
\hline Units & $\mathbf{n}$ & $\%$ \\
\hline Hospitalized in the ward & 566 & 86 \\
\hline Patients admitted to the intensive care unit & 92 & 14 \\
\hline \multicolumn{3}{|l|}{ Sex } \\
\hline Woman & 358 & 54.4 \\
\hline Man & 300 & 45.6 \\
\hline \multicolumn{3}{|l|}{ Chest computed tomography } \\
\hline No COVID-19* findings & 76 & 11.6 \\
\hline Typical COVID-19 findings & 494 & 75.0 \\
\hline Atypical findings & 88 & 13.4 \\
\hline \multicolumn{3}{|l|}{ Comorbidities } \\
\hline No & 419 & 63.7 \\
\hline Yes & 239 & 36.3 \\
\hline Cardiovascular diseases & 159 & 43.2 \\
\hline Hypertension & 113 & 30.7 \\
\hline Coronary artery disease & 36 & 9.78 \\
\hline Others & 10 & 2.71 \\
\hline Respiratory diseases & 37 & 10.05 \\
\hline Asthma & 21 & 5.7 \\
\hline Chronic obstructive pulmonary disease & 15 & 4.07 \\
\hline Others & I & 0.27 \\
\hline Endocrinological diseases & 88 & 23.91 \\
\hline Diabetes mellitus & 81 & 22.01 \\
\hline Hypo/hyperthyroidism & 6 & 1.63 \\
\hline Others & I & 0.27 \\
\hline Renal diseases & 20 & 5.43 \\
\hline Chronic kidney disease & 16 & 4.34 \\
\hline Others & 4 & 1.08 \\
\hline Neurological diseases & 29 & 7.88 \\
\hline Cerebrovascular disease & 12 & 3.26 \\
\hline Dementia/Alzheimer's & 5 & 1.35 \\
\hline Others & 12 & 3.26 \\
\hline Oncological diseases & 9 & 2.44 \\
\hline Other diseases & 26 & 7.06 \\
\hline
\end{tabular}

*Coronavirus disease-2019.

nificantly higher in patients admitted to the ICU than those of discharged patients (APACHE II, $\mathrm{p}<0.00 \mathrm{I}$; SOFA, $\mathrm{p}<0.00 \mathrm{I}$ ). When the groups were compared in terms of laboratory values, WBC counts, neutrophil counts, lymphocyte counts, N/L ratio, and levels of CRP, LDH, CK, PTZ, D-dimer, procalcitonin, and ferritin were found to be significantly higher in patients admitted to the ICU $(p<0.001$ for all values, for CK $p=0.034)$. Conversely, there was no significant difference between the groups in terms of platelet and aPTT levels
Table 2. Comparison of patients hospitalized in the ward and intensive care unit I

\begin{tabular}{|c|c|c|c|}
\hline \multirow[t]{2}{*}{ Characteristics } & \multirow{2}{*}{$\begin{array}{c}\begin{array}{c}\text { Group I } \\
(n=566)\end{array} \\
n(\%)\end{array}$} & \multirow{2}{*}{$\begin{array}{c}\begin{array}{c}\text { Group } 2 \\
(\mathrm{n}=92)\end{array} \\
n(\%)\end{array}$} & \multirow[t]{2}{*}{$\mathbf{p}^{*}$} \\
\hline & & & \\
\hline \multicolumn{4}{|l|}{ Sex } \\
\hline Female & $309(47)$ & $49(7.4)$ & 0.81 \\
\hline Male & $257(39.1)$ & $43(6.5)$ & \\
\hline \multicolumn{4}{|l|}{ Blood group } \\
\hline$A$ & $213(40.3)$ & $45(8.5)$ & 0.99 \\
\hline B & $79(14.9)$ & $17(3.2)$ & \\
\hline$A B$ & $43(8.1)$ & $9(1.7)$ & \\
\hline O & $102(19.3)$ & $21(4)$ & \\
\hline \multicolumn{4}{|l|}{$\mathrm{Rh}$} \\
\hline Negative & $54(10.2)$ & $9(1.7)$ & 0.48 \\
\hline Positive & $383(72.4)$ & $83(15.7)$ & \\
\hline \multicolumn{4}{|l|}{ KDIGO\# } \\
\hline Stage 0 & $536(81.5)$ & $38(5.8)$ & $<0.001$ \\
\hline Stage I & $23(3.5)$ & $25(3.8)$ & \\
\hline Stage 2 & $4(0.6)$ & $19(2.9)$ & \\
\hline Stage 3 & $3(0.5)$ & $10(1.5)$ & \\
\hline \multicolumn{4}{|l|}{ Chest computed } \\
\hline \multicolumn{4}{|l|}{ tomography } \\
\hline No result & $72(\mathrm{II})$ & $4(0.6)$ & 0.03 \\
\hline COVID-19 compatible & $420(64.1)$ & $74(11.1)$ & \\
\hline \multicolumn{4}{|l|}{ Atypical/questionable } \\
\hline results & $71(10.8)$ & $17(2.6)$ & \\
\hline \multicolumn{4}{|l|}{ Comorbidity } \\
\hline No & $406(6 I .7)$ & $13(2)$ & $<0.001$ \\
\hline Yes & $160(24.3)$ & $79(12)$ & \\
\hline
\end{tabular}

"Chi-squared/Fisher's exact tests p-value, "Kidney Disease: Improving global outcomes score.

( $p=0.46, p=0.66$, respectively). In addition, the number of days of hospital stay was significantly higher in patients admitted to the ICU $(p<0.00 I)$ (Table 3).

When comparing the clinical conditions of the patients admitted to the ICU and subsequently intubated (Group I, $\mathrm{n}=63$ ) or not intubated (Group $\mathrm{NI}, \mathrm{n}=29$ ) during their first admission the ICU, it was observed that the patients who were intubated had more comorbidities $(p<0.001)$ and a significantly higher mortality rate than those who were not intubated $(p<0.00 \mathrm{I})$. When the patients in Group I and Group $\mathrm{NI}$ were compared in terms of age, the mean age of the patients in Group I was significantly higher than those in Group $\mathrm{NI}$ (Group I=69.49, Group NI=57.65; $\mathrm{p}=0.008$ ). When the groups were compared in terms of laboratory findings at first 
Table 3. Comparison of patients hospitalized in the ward and intensive care unit 2

\begin{tabular}{|c|c|c|c|}
\hline \multirow[t]{2}{*}{ Characteristics } & \multirow{2}{*}{$\frac{\text { Group I }(n=566)}{\text { Mean (Min-Max) }}$} & \multirow{2}{*}{$\frac{\text { Group } 2(n=92)}{\text { Mean (Min-Max) }}$} & \multirow[t]{2}{*}{$\mathbf{p}^{*}$} \\
\hline & & & \\
\hline Age (years) & $46.4(18-89)$ & $65.76(23-92)$ & $<0.001$ \\
\hline Apache II" & $4.72(I-23.0)$ & $15.88(3-40.0)$ & $<0.001$ \\
\hline SOFA $^{\&}$ & $2.17(1-6.0)$ & $3.88(2-12.0)$ & $<0.001$ \\
\hline White blood cell count $\left(\times 10^{3} / \mathrm{uL}\right)$ & $6.66(2.2-33.1)$ & $12.7(1.13-159)$ & $<0.001$ \\
\hline Neutrophil $\left(\times 10^{3} / \mathrm{uL}\right)$ & $4.5(1.08-31.4)$ & $8.8(0.6-37.5)$ & $<0.001$ \\
\hline Lymphocyte (×103/uL) & $1.61(0.32-17.2)$ & $3.09(0.19-146.2)$ & $<0.001$ \\
\hline Neutrophil-lymphocyte ratio & $3.4(0.21-43)$ & $9.72(0.04-63.37)$ & $<0.001$ \\
\hline Platelet count $\left(\times 10^{3} / \mathrm{uL}\right)$ & $218.54(68-658)$ & $233.74(50-67 I)$ & 0.46 \\
\hline C-reactive protein $(\mathrm{mg} / \mathrm{L})$ & $25.91(1.0-302.8)$ & $1 \mid 6.92(2-3 \mid 2)$ & $<0.001$ \\
\hline Lactate dehydrogenase (U/L) & $254.64(18-3814)$ & 363.77 (139-875) & $<0.001$ \\
\hline Creatine kinase (IU/L) & $190.6(|2-544|)$ & $227.72(14-2756)$ & 0.034 \\
\hline Prothrombin time (s) & $12.66(9.5-37.3)$ & $13.43(1.44-33.8)$ & $<0.001$ \\
\hline Activated partial thromboplastin time (s) & $31.14(18.3-94.6)$ & $31.09(20.5-44.7)$ & 0.66 \\
\hline D-dimer (ng/ml) & $254.3(11-3719)$ & $1115.9(67-18890)$ & $<0.001$ \\
\hline Procalcitonin (ng/ml) & $0.14(0.02-1.34)$ & $1.98(0.3-27.4)$ & $<0.001$ \\
\hline Ferritin $(\mu g / L)$ & $245.67(3-2000)$ & $648.99(34-2000)$ & $<0.001$ \\
\hline Hospitalization period (days) & $6.57(I-27)$ & $15.82(2-8 \mid)$ & $<0.001$ \\
\hline
\end{tabular}

*Mann-Whitney U test p-value, \#Acute Physiology and Chronic Health Evaluation II score, ${ }^{\text {\& }}$ Sequential Organ Failure Assessment score.

admission to the ICU, the D-dimer and ferritin levels were significantly higher in the patients in Group I $(p=0.01 \mathrm{I}$ and 0.043, respectively) (Table 4).

When 63 patients that were admitted to the ICU and intubated were divided into two groups as those who died (Group $M, n=47)$ and those who survived $(N M=16)$ and examined, it was observed that the patients in Group $M$ were mostly males $(p=0.017)$ and were mostly in KDIGO Stages I and $2(p=0.005)$. When patients in Groups $M$ and NM were compared in terms of age, laboratory findings, and length of stay in the ICU, it was found that the CRP and LDH levels of patients in Group $M$ were significantly higher than those in Group NM ( $p=0.018$ and 0.023 , respectively). However, there was no statistically significant difference between the two groups in terms of age, length of stay in the ICU, and other laboratory findings (Table 5).

\section{DISCUSSION}

In this study, factors affecting the clinical course of the disease in hospitalized patients due to COVID-19 were investigated. At the end of the study, it was determined that age, gender, comorbidity, APACHE II and SOFA scoring systems, KDIGO staging and some laboratory values (higher WBC counts, neutrophil counts, lymphocyte counts, N/L ratio, CRP, LDH, CK, PTZ, D-dimer, procalcitonin ve ferritin values) could be useful in predicting the course of the disease.
APACHE II and SOFA are the scoring systems commonly used in ICUs for assessing critical illness severity and mortality. ${ }^{[12]}$ It has been reported that these two scoring systems can be used for predicting disease severity in SARS-CoV-2 infection. ${ }^{[12-14]}$ In our study, both APACHE II and SOFA scores were significantly higher in COVID- 19 patients who required ICU admission compared to those who did not. However, there was no statistically significant difference between the patients who were intubated and those who were not, and patients who died or survived among those who were intubated. The results of our study demonstrate that APACHE II and SOFA scoring systems can be a marker for patients needing ICU admission, but not for patients needing intubation and for mortality in intubated patients.

In various studies examining the relationship between age and COVID-19, it was reported that SARS-CoV-2 infection was more severe in elderly patients. ${ }^{[13-16]}$ Furthermore, in a study on 463 COVID-19 patients in Detroit, it was stated that male sex and being aged $>60$ years had a significant relationship with mortality. ${ }^{[17]}$ In our study, ages of patients requiring ICU admission and intubation after ICU admission were significantly higher; however, age did not affect mortality in intubated patients. According to our study results, SARS-CoV-2 infection was more severe in elderly patients, resulting in the need for ICU admission and intubation being higher in these patients. 
Table 4. Comparison of intubated and non-intubated patients in the intensive care unit

\begin{tabular}{|c|c|c|c|}
\hline \multirow[t]{2}{*}{ Characteristics } & \multirow{2}{*}{$\frac{\text { Group I }(n=63)}{\text { Mean (Min-Max) }}$} & \multirow{2}{*}{$\frac{\text { Group NI }(n=29)}{\text { Mean (Min-Max) }}$} & \multirow[t]{2}{*}{$\mathbf{p}^{*}$} \\
\hline & & & \\
\hline Age (years) & $69.49(26-92)$ & $57.65(23-83)$ & 0.008 \\
\hline Apache II & $16.77(3-39)$ & $13.93(5-40)$ & $0.77^{*+1}$ \\
\hline SOFA ${ }^{\&}$ & $4.04(2-12)$ & $3.5 \mid(2-9)$ & 0.15 \\
\hline White blood cell count $\left(\times 10^{3} / u L\right)$ & II.38 (I.I3-55.7) & $10.8(3.1-42.7)$ & 0.51 \\
\hline Neutrophil $\left(\times 10^{3} / \mathrm{uL}\right)$ & $8.85(0.6-22.2)$ & $8.83(2.27-37.5)$ & $0.98^{\text {tex }}$ \\
\hline Lymphocyte $\left(\times 10^{3} / \mathrm{uL}\right)$ & $1.75(0.19-28.7)$ & I. $47(0.43-6.8)$ & 0.3 \\
\hline Neutrophil-lymphocyte ratio & $10.46(0.34-63.37)$ & $8.14(0.84-26)$ & 0.29 \\
\hline Platelet count $\left(\times 10^{3} / \mathrm{uL}\right)$ & $232.6(50-628)$ & $236.03(84-67 I)$ & $0.89^{\text {sit }}$ \\
\hline C-reactive protein (mg/L) & I $22.7(3.4-297.8)$ & $104.22(2-3 \mid 2.3)$ & 0.17 \\
\hline Lactate dehydrogenase (U/L) & $370.1(139-816)$ & $350.03(148-875)$ & $0.56^{\text {** }}$ \\
\hline Creatine kinase (IU/L) & $271.1(14-2756)$ & $133.28(23-455)$ & 0.08 \\
\hline Prothrombin time (s) & $13.7(10.9-33.8)$ & $13.23(\mid 1.2-17.2)$ & 0.4 \\
\hline Activated partial thromboplastin time (s) & $30.4(20.5-44.4)$ & $32.4(22.6-44.7)$ & $0.11^{\text {*h }}$ \\
\hline D-dimer (ng/ml) & $1340.6(67-18890)$ & $658.7(75-2824)$ & 0.011 \\
\hline Procalcitonin (ng/ml) & $2.15(0.04-18.52)$ & $1.68(0.03-27.4)$ & 0.07 \\
\hline Ferritin $(\mu g / L)$ & $744.4(34-2000)$ & $433.5(45-1370)$ & 0.043 \\
\hline $\begin{array}{l}\text { The number of days spent in the intensive } \\
\text { care unit (days) }\end{array}$ & $16.47(2-8 \mid)$ & $|4.4|(5-32)$ & 0.64 \\
\hline
\end{tabular}

*Mann-Whitney U test p-value, "'Student-t test P value, "Acute Physiology and Chronic Health Evaluation II score, ${ }^{8}$ Sequential Organ Failure Assessment score.

The possibility of sex being a risk factor for COVID-19 has been examined in some studies. ${ }^{[3,13,15-17]}$ Yang et al. ${ }^{[15]}$ reported that the majority of critically ill patients $(67 \%)$ were males in their study, which included 52 critically ill patients out of 710 patients with SARS-CoV-2 pneumonia. Contrary to these studies, Yao et al. ${ }^{[13]}$ studied 108 patients and reported no difference in terms of sex between those who had a severe disease and those who did not. In our study, no difference was found between patients admitted to the ICU and those discharged from the wards in terms of sex.

In a retrospective study on 1590 patients in China, patients with and without comorbidities were compared, and it was found that the number of patients with severe disease was higher in patients with comorbidities. ${ }^{[4]} \mathrm{A}$ meta-analysis on COVID-19 stated that the prevalence of comorbidities was $36.8 \%$, the most common comorbidity was hypertension, and the presence of comorbidities was significantly associated with mortality in COVID-19. ${ }^{[18]}$ In our study, 239 patients (36.3\%) had at least one comorbidity, of which hypertension was the most common, which is consistent with the existing literature. The number of comorbidities was significantly higher in patients requiring ICU admission compared to those followed up in wards; it was also higher in those admitted to the ICU and intubated compared to those who were not intubated.
However, when the intubated patients were compared, no statistically significant difference was observed in terms of comorbidities between those who died and those who survived. This suggests that patients with comorbidities need ICU admission and intubation more frequently, but the comorbidities do not affect mortality after the patients have been intubated.

It has been reported that the SARS-CoV-2 infection has a severe course and the incidence of acute renal damage is high in patients who died. ${ }^{[13]}$ In our study, we evaluated acute renal damage using the KDIGO staging system. The number of patients in KDIGO Stages I-2-3 was significantly higher in the group of patients requiring ICU admission (Group 2 vs. Group I) and in the group of intubated patients in the ICU who died (Group M vs. Group NM) compared to the other groups. This indicates that the need for ICU admission and mortality were higher in patients with acute renal damage.

It has been stated that the most common laboratory findings in COVID-19 patients are lymphopenia, low albumin, and high CRP and $\mathrm{LDH}^{\left[{ }^{[8]}\right.}$ In addition, it has been reported that lymphopenia is a risk factor for severe SARS-CoV-2 infection, and that the WBC and neutrophil counts are significantly higher in patients who died. ${ }^{[13]}$ Some studies state that high N/L ratio is associated with poor clinical outcomes 
Table 5. Comparison of intubated patients in intensive care unit in terms of mortality

\begin{tabular}{|c|c|c|c|}
\hline \multirow[t]{2}{*}{ Characteristics } & \multirow{2}{*}{$\frac{\text { Group } M(n=47)}{\text { Mean (Min-Max) }}$} & \multirow{2}{*}{$\frac{\text { Group NM }(n=16)}{\text { Mean (Min-Max) }}$} & \multirow[t]{2}{*}{$\mathbf{p}^{*}$} \\
\hline & & & \\
\hline Age (years) & $70.9(4 \mid-9 I)$ & $65.1(26-92)$ & $0.14^{* *}$ \\
\hline Apache II & $17.3(8-39)$ & I5.I (3-28) & $0.28^{* *}$ \\
\hline SOFA ${ }^{\&}$ & $4.06(2-12)$ & $4(2-8)$ & 0.94 \\
\hline White blood cell count $\left(\times 10^{3} / \mathrm{uL}\right)$ & II.39 (I.I-55.7) & II.35 (4.3-25.4) & 0.58 \\
\hline Neutrophil $\left(\times 10^{3} / \mathrm{uL}\right)$ & $8.64(0.6-21.5)$ & $9.47(3.4-22.2)$ & $0.55^{* *}$ \\
\hline Lymphocyte $\left(\times 10^{3} / \mathrm{uL}\right)$ & $1.92(0.19-28.7)$ & $1.26(0.4-2.1)$ & 0.14 \\
\hline Neutrophil-lymphocyte ratio & II.I (0.34-63.3) & $8.46(2.5-28.7)$ & 0.57 \\
\hline Platelet count $\left(\times 10^{3} / \mathrm{uL}\right)$ & $244.5(50-628)$ & 197.7 (109-288) & $0.11^{* *}$ \\
\hline C-reactive protein (mg/L) & $136.5(3.4-297.8)$ & $82.4(5-240)$ & $0.018^{* *}$ \\
\hline Lactate dehydrogenase (U/L) & $392.9(198-816)$ & $303(139-636)$ & 0.023 \\
\hline Creatine kinase (IU/L) & $253.1(14-1976)$ & $324.3(28-2756)$ & 0.32 \\
\hline Prothrombin time (s) & $14.09(11.3-33.8)$ & $12.9(10.9-17.2)$ & $0.43^{* *}$ \\
\hline Activated partial thromboplastin time (s) & $30.2(20.5-44.4)$ & $30.9(22.8-39.7)$ & $0.67^{* *}$ \\
\hline D-dimer (ng/ml) & $1557.3(67-18890)$ & $758.1(171-4195)$ & 0.22 \\
\hline Procalcitonin (ng/ml) & $2.48(0.07-18.52)$ & $1.32(0.04-12.52)$ & 0.07 \\
\hline Ferritin $(\mu \mathrm{g} / \mathrm{L})$ & $830.8(34-2000)$ & $560.6(47-2000)$ & $0.15^{* *}$ \\
\hline $\begin{array}{l}\text { The number of days spent in the intensive } \\
\text { care unit (days) }\end{array}$ & I5.I (2-79) & $20.2(5-8 I)$ & 0.27 \\
\hline
\end{tabular}

*Mann-Whitney U test p-value, "'Student-t test P value, "Acute Physiology and Chronic Health Evaluation II score, ${ }^{8}$ Sequential Organ Failure Assessment score.

and can be used for determining the severity of SARS-CoV-2 infection. ${ }^{[19,20]}$ In our study, WBC, neutrophil, and lymphocyte counts as well as $\mathrm{N} / \mathrm{L}$ ratio were significantly higher in the patient group requiring ICU admission. However, there were no significant differences in these parameters between ICU admitted patients who were intubated and those who were not in addition to those who died and those who survived. In our study, lymphocytosis in patients requiring ICU admission contradicted with the findings of lymphopenia in other studies. This was an unexpected result. We thought that the reason for this unexpected result might be due to the treatments that ICU patients received while they were in the ward. Our study suggested that lymphopenia was not a marker for the need of intubation and for mortality in COVID-19 patients who required ICU admission; however, high WBC, neutrophil, and lymphocyte counts and high $N / L$ ratio may be a marker for progression to severe disease.

It has been stated in some studies that high CRP levels are a common finding in COVID-19 patients and that it progresses to higher levels in severe cases. ${ }^{[13,18,21,22]}$ In a study on 138 patients conducted by Wang et al.,. ${ }^{[23]}$ no significant difference was found between patients admitted to the ICU and the other patients in terms of CK levels, but CK-MB and LDH levels were significantly higher in patients admitted to the
ICU. In our study, CRP, CK, and LDH levels were higher in patients admitted to the ICU; however, there was no difference between patients who were intubated and those who were not. Moreover, CRP and LDH levels were significantly higher in intubated patients who died compared to those who survived. These results suggest that CRP, CK, and LDH levels may be a marker for patients requiring ICU admission and that CRP and LDH levels could be markers for mortality in patients who undergo intubation.

Changes in parameters related to coagulation in COVID-19 patients have been examined in some publications. A study emphasized that hypercoagulopathy was common in patients with SARS-CoV-2 infection, and it was stated that life-threatening disseminated intravascular coagulation can be observed, especially in hospitalized patients, in addition to other coagulation abnormalities such as PT and aPTT prolongation with elevated D-dimer levels, increased fibrin degradation products, and severe thrombocytopenia. Hence, it has been stated that platelet count, PT, fibrinogen, D-dimer, antithrombin, and Protein- $\mathrm{C}$ monitoring can be used to determine the prognosis in early diagnosis and follow-up. ${ }^{[24]}$ Elshazli et al. ${ }^{[25]}$ suggested that high WBC, neutrophil, D-dimer, and prolonged PT levels may be associated with increased probability of ICU admission; additionally, high IL-6, CRP, D-dimer, and 
neutrophil levels may be associated with high mortality. Besides these, various studies have also emphasized that D-dimer and prolonged PT levels can be a marker for determining disease severity and mortality. ${ }^{[13,26,27]}$ In our study, D-dimer and PT levels were significantly higher in patients requiring ICU admission, but there was no statistically significant difference in terms of platelet count at any stage of the study. In addition, D-dimer levels were significantly higher in patients who were intubated than those who were not. There was no statistically significant difference in terms of D-dimer and PT in patients who died or survived after being intubated. This suggests that D-dimer and PT can be used as markers for patients requiring $\mathrm{ICU}$ admission and intubation.

Finally, considering the correlation of PCT and ferritin levels with COVID-19, Zhang et al. ${ }^{[14]}$ found that PCT levels were significantly higher in patients with a severe disease. The same result was reported by Yao et al. ${ }^{[13]}$ In addition, Suleyman et al. ${ }^{[17]}$ studied 463 patients in Detroit and found that ferritin and PCT levels were higher in patients admitted to the ICU compared to those who were not. In our study, PCT and ferritin levels were significantly higher in patients requiring ICU admission. In addition, although PCT and ferritin levels were higher in patients who were intubated compared to those who were not, only ferritin levels were statistically significant. No difference was observed in terms of PCT and ferritin levels in intubated patients who died or survived. These results indicate that ferritin levels can be a marker for the need of ICU admission and intubation, and that PCT levels can be a marker for determining the need for ICU admission.

\section{Conclusion}

Comorbidity, clinical features, and laboratory findings are parameters that can help in predicting the clinical course of hospitalized patients due to COVID-2019. We believe that these results provide information on disease prognosis in hospitalized COVID-19 patients. Hence, evaluating patients for these parameters may be helpful in determining the prognosis of the disease.

\section{Limitation}

The most important limitation of our study is that it was retrospective and single centered. Conducting studies on the subject, nationwide or worldwide, with multiple centers and large patient populations will provide more precise information. Another limitation of our study was the investigation of CRP, LDH, and CK levels, which were biochemically, indicated as a prognostic factor for critically ill patients. A study that includes other biochemical values as well is currently planned. Finally, due to insufficient data on patients' application complaints, these features were not included in our study.

Ethics Committee Approval: This study was approved by the Diyarbakir Gazi Yasargil Traning and Research Hospital Ethics Committee (Date: 15.05.2020, Decision No: 470).
Peer-review: Internally peer-reviewed.

Authorship Contributions: Concept: O.U., A.Y.; Design: O.U., A.Y.; Supervision: O.U., A.Y.; Resource: O.U., A.Y.; Materials: O.U., C.K.K., H.A., M.S.G., D.K., Ü.A., A.Y.; Data: O.U., C.K.K., H.A., M.S.G., D.K., Ü.A., A.Y.; Analysis: O.U., C.K.K., H.A., M.S.G., D.K., Ü.A., A.Y.; Literature search: O.U., C.K.K., H.A., M.S.G., D.K., Ü.A., A.Y.; Writing: O.U., C.K.K., H.A., M.S.G., D.K., Ü.A., A.Y.; Critical revision: O.U., C.K.K., A.Y.

Conflict of Interest: None declared.

Financial Disclosure: The authors declared that this study has received no financial support.

\section{REFERENCES}

1. Xie M, Chen Q. Insight into 2019 novel coronavirus-an updated interim review and lessons from SARS-CoV and MERS-CoV. Int J Infect Dis 2020;94:119-24. [CrossRef]

2. World Health Organization Coronavirus Disease (COVID-19) Dashboard. Available from: https://www.covid19.who,int. Accessed Dec 01, 2020.

3. Huang C, Wang Y, Li X, Ren L, Zhao J, Hu Y, et al. Clinical features of patients infected with 2019 novel coronavirus in Wuhan, China. Lancet 2020;395:497-506. [CrossRef]

4. Guan WJ, Liang WH, Zhao Y, Liang HR, Chen ZS, Li YM, et al. Comorbidity and its impact on 1,590 patients with Covid-19 in China: A nationwide analysis. Eur Respir J 2020;55:2000547. [CrossRef]

5. Yan Y, Yang Y, Wang F, Ren H, Zhang S, Shi X, et al. Clinical characteristics and outcomes of patients with severe covid-19 with diabetes. BMJ Open Diabetes Res Care 2020;8:1343. [CrossRef]

6. Guzik TJ, Mohiddin SA, Dimarco A, Patel V, Savvatis K, Marelli-Berg FM, et al. COVID-19 and the cardiovascular system: Implications for risk assessment, diagnosis, and treatment options. Cardiovasc Res 2020;116:1666-87. [CrossRef]

7. Richardson S, Hirsch JS, Narasimhan M, Crawford JM, McGinn T, Davidson KW, et al. Presenting characteristics, comorbidities, and outcomes among 5700 patients hospitalized with COVID-19 in the New York city area. JAMA 2020;323:2052. [CrossRef]

8. Clinical Management of COVID-19. Available from: https://www.who. $\mathrm{int} /$ publications/i/item/clinical-management-of-covid-19. Accessed Oct 25, 2020.

9. T.C. Sağlık Bakanliği COVID-19 Bilgilendirme Sayfası. Ağır Pnömoni, ARDS, Sepsis ve Septik Şok Yönetimi. Available from: https://www. mcovid19.saglik.gov.tr/TR-66340/agir-pnomoni-ards-sepsis-ve-septik-sok-yonetimi.html. Accessed Oct 25, 2020.

10. Bao C, Liu X, Zhang H, Li Y, Liu J. Coronavirus disease 2019 (COVID-19) CT findings: A systematic review and meta-analysis. J Am Coll Radiol 2020;17:701-9. [CrossRef]

11. Hani C, Trieu NH, Saab I, Dangeard S, Bennani S, Chassagnon G, et al. COVID-19 pneumonia: A review of typical CT findings and differential diagnosis. Diagn Interv Imaging 2020;101:263-8. [CrossRef]

12. Zou X, Li S, Fang M, Hu M, Bian Y, Ling J, et al. Acute physiology and chronic health evaluation II score as a predictor of hospital mortality in patients of coronavirus disease 2019. Crit Care Med 2020;48:E657-65.

13. Yao Q, Wang P, Wang X, Qie G, Meng M, Tong X, et al. A retrospective study of risk factors for severe acute respiratory syndrome coronavirus 2 infections in hospitalized adult patients. Polish Arch Intern Med 2020;130:390-9. 
14. Zhang G, Hu C, Luo L, Fang F, Chen Y, Li J, et al. Clinical features and short-term outcomes of 221 patients with COVID-19 in Wuhan, China. J Clin Virol 2020;127:104364. [CrossRef]

15. Yang X, Yu Y, Xu J, Shu H, Xia J, Liu H, et al. Clinical course and outcomes of critically ill patients with SARS-CoV-2 pneumonia in Wuhan, China: A single-centered, retrospective, observational study. Lancet Respir Med 2020;8:475-81. [CrossRef]

16. Du RH, Liu LM, Yin W, Wang W, Guan LL, Yuan ML, et al. Hospitalization and critical care of 109 decedents with COVID-19 pneumonia in Wuhan, China. Ann Am Thorac Soc 2020;17:839-46. [CrossRef]

17. Suleyman G, Fadel RA, Malette KM, Hammond C, Abdulla H, Entz A, et al. Clinical characteristics and morbidity associated with coronavirus disease 2019 in a series of patients in metropolitan detroit. JAMA Netw Open 2020;3:e2012270. [CrossRef]

18. Rodriguez-Morales AJ, Cardona-Ospina JA, Gutiérrez-Ocampo E, Villamizar-Peña R, Holguin-Rivera Y, Escalera-Antezana JP, et al. Clinical, laboratory and imaging features of COVID-19: A systematic review and meta-analysis. Travel Med Infect Dis 2020;34:101623. [CrossRef]

19. Yang A, Liu J, Tao W, Li H. The diagnostic and predictive role of NLR, d-NLR and PLR in COVID-19 patients. Int Immunopharmacol 2020;84:106504. [CrossRef]

20. Lagadinou M, Solomou EE. Prognosis of COVID-19: Changes in labo- ratory parameters. Le Infez Med 2020;28:89-95.

21. Liu F, Li L, Xu MD, Wu J, Luo D, Zhu YS, et al. Prognostic value of interleukin-6, C-reactive protein, and procalcitonin in patients with COVID-19. J Clin Virol 2020;127:104370. [CrossRef]

22. Sun Y, Dong Y, Wang L, Xie H, Li B, Chang C, et al. Characteristics and prognostic factors of disease severity in patients with COVID-19: The Beijing experience.J Autoimmun 2020;112:102473. [CrossRef]

23. Wang D, Hu B, Hu C, Zhu F, Liu X, Zhang J, et al. Clinical characteristics of 138 hospitalized patients with 2019 novel coronavirus-infected pneumonia in Wuhan, China. JAMA 2020;323:1061-9. [CrossRef]

24. Terpos E, Ntanasis-Stathopoulos I, Elalamy I, Kastritis E, Sergentanis TN, Politou M, et al. Hematological findings and complications of COVID-19. Am J Hematol 2020;95:834-47. [CrossRef]

25. Elshazli RM, Toraih EA, Elgaml A, El-Mowafy M, El-Mesery M, Amin $\mathrm{MN}$, et al. Diagnostic and prognostic value of hematological and immunological markers in COVID-19 infection: A meta-analysis of 6320 patients. PLoS One 2020;15:e0238160. [CrossRef]

26. Yao Y, Cao J, Wang Q, Shi Q, Liu K, Luo Z, et al. D-dimer as a biomarker for disease severity and mortality in COVID-19 patients: A case control study. J Intensive Care 2020;8:49. [CrossRef]

27. Aboughdir M, Kirwin T, Khader AA, Wang B. Prognostic value of cardiovascular biomarkers in COVID-19: A review. Viruses 2020;12:527.

\section{ORIJINAL ÇALIŞMA - ÖZET}

\section{COVID-19 hastalarında hastalığın seyrini belirleyen göstergeler}

\section{Dr. Osman Uzundere, ${ }^{1}$ Dr. Cem Kıvılcım Kaçar, ${ }^{1}$ Dr. Hakan Akelma, ${ }^{1}$ Dr. Mehmet Salih Gül, ${ }^{1}$ Dr. Deniz Kandemir, ${ }^{1}$ Dr. Ümit Akol, ${ }^{1}$ Dr. Abdulkadir Yektaş ${ }^{2}$}

${ }^{1}$ Sağlık Bilimleri Üniversitesi Diyarbakır Gazi Yaşargil Eğitim ve Araştırma Hastanesi, Anesteziyoloji ve Reanimasyon Anabilim Dalı, Diyarbakır ${ }^{2}$ Sağlık Bilimleri Üniversitesi Diyarbakır Gazi Yaşargil Eğitim ve Araştırma Hastanesi, Genel Yoğun Bakım Ünitesi, Diyarbakır

AMAÇ: Bu çalışmada, koronavirüs hastalı̆̆-2019 nedeniyle hastanede takip edilen hastalarda klinik sürece etkili olan faktörler saptanmaya çalışıldı. GEREÇ VE YÖNTEM: Tek merkezli ve geriye dönük kohort olarak dizayn edilen çalışmaya koronavirüs hastalığı-20। 9 hastalı̆̆ı nedeniyle servise ya$\tan 658$ hasta dahil edildi. Çalışmaya alınan hastalar öncelikle serviste takip edilenler (Grup I) ve yoğun bakım ünitesine alınanlar (Grup 2) şeklinde; sonrasında yoğun bakım ünitesine alınan hastalar, entübe edilenler (Grup I) ve edilmeyenler (Grup NI) olarak ve son olarak entübe edilen hastalar, mortal olanlar (M) ve olmayanlar (NM) olarak gruplandırıldı ve karşılaştıııldı.

BULGULAR: Çalışmaya alınan 658 hastanın 566'sı (\%86) serviste takip edilip taburcu edilirken 99'u (\%।4) yoğun bakım ünitesine alınmıştı. Takip edilen 658 hastanın ölüm oranı \%7.75 olarak bulundu. Grup I ve 2 karşısştıııığında Grup 2'deki hastaların daha fazla komorbiditeye ve daha yüksek KDIGO skorlarına sahip olduğu gözlendi $(\mathrm{p}<0.00 \mathrm{I})$. Ayrıca Grup 2'deki hastaların daha ileri yaş, daha yüksek APACHE II ve SOFA skorları, WBC, nötrofil, lenfosit, N/L oranı, CRP, LDH, CK, PTZ, D-dimer, prokalsitonin and ferritin değerlerine sahip olduğu gözlendi (bütün özellikler için $p<0.00$ I, CK için $p=0.034$ ). Grup I ve NI karşılaştıııldığında Grup l'daki hastaların daha fazla komorbiditeye sahip olduğu ve yükssek mortalite oranlarına sahip olduğu gözlendi $(p<0.001)$. Ayrıca Grup l'daki hastalar daha ileri yaş, yüksek D-dimer ve ferritin düzeylerine sahipti (sırasıyla, $p=0.008 ; 0.011$ ve 0.043 ). Son olarak Grup M ve NM karşılaştıııldığında Grup M'deki hastaların çoğunlukla erkek ( $=0.017)$ ve KDIGO evre I ve 2'deki hastalardan oluştuğu ( $p=0.005$ ) gözlendi. Ayrıca Grup M'deki hastaların daha yüksek CRP ve LDH değerlerine sahip olduğu saptandı (sırasıyla, $p=0.018$ ve 0.023 ).

TARTIŞMA: Komorbidite, klinik özellikler ve laboratuvar bulguları koronavirüs hastalı̆̆-20। 9 nedeniyle hastaneye yatırılan hastaların klinik seyrini tahmin etmede yardımcı olabilecek parametrelerdir.

Anahtar sözcükler: COVID-19; klinik özellikler; yoğun bakım ünitesi.

Ulus Travma Acil Cerrahi Derg 2021;27(6):668-676 doi: 10.14744/tjtes.2021.06634 